\title{
Contrastive Analysis of English and Likuba Greetings
}

\author{
Gemma Cliff Nguia Oniangué \\ Université Marien Ngouabi, Faculté des Lettres, Arts et Sciences Humaines \\ *Corresponding Author: Gemma Cliff Nguia Oniangué, Université Marien Ngouabi, Faculté des \\ Lettres, Arts et Sciences Humaines

\begin{abstract}
In their everyday life, human beings everywhere throughout the world have some practices for their social interaction. Greetings which are part of these practices constitute my issue. I do not share the view that greetings are not content-based. To achieve this analysis, I resort to inductive, comparative and pragmatic approaches.
\end{abstract}

Keywords: human beings; practices; social interaction; greetings; view; analysis.

\section{INTRODUCTION}

Socialization is part of fundamental principles of the constitution of every linguistic community. As a matter of fact, it implies several parameters among which speech acts in general and greetings in particular. Actually, greetings make the social wheel turns smoothly through different purposes from one social group to another. Accordingly, Harnich and Bach (1979:51-52) state that greetings merely express pleasure and a way of establishing contact between individuals. But this statement raises some questions in my mind which can be expressed as follows: Are greetings considered as a mere expression of pleasure and a way of establishing contact between individuals? This problematic is inthe connection with the following hypothesis: every linguistic community has specificities related to speech acts in general and greetings in particular. This studyis going to carry out the social impact of English and Likuba greetings. Note that Likuba language is spoken in Mossaka, Cuvette Department in the northern part of Congo.

My motivation to embark on this study derives from the song of the Congolese singers ZobaCasimir "Alias Zao" on different greetings through the world and the song "Bonjour" of Patrice NgoyMussoko, a DRC musician. As a matter of fact, through their songs, greetings are not context based. Furthermore, the study of Lumela/Lumela: A socio-Pragmatic Analysis of Sesotho Greetings written by Akindele (2017) could not prevent me from embarking myself on this topic. Accordingly, this author based his work on types, structural organization and Sesotho greeting functions. Then, the reading of Etude comparée des salutations Françaises et Yorubas written by Iyiola Amos Damilare (2015:7-17 )has also been one of my of motivations. In fact, this author talked about similarities and dissimilarities between French and Yorubas basing on contextual aspects. However, both authors did not tell anything on proverbial greetings, one aspect of speech acts whose studies seem trivial by researchers. Finally, I am boosted by the fact that the study of any language is not only made of structural aspect; but also, it takes into consideration some social parameters. In this respect, Akindele (2007:1) writes:

"In studying and using any particular language, it is not sufficient to master the phonology, syntax, lexis and morphology as mark of communicative competence. The basic discourse rules or conversational routines of such a language are highly essential. These routines include among others how greetings, compliments, invitations and the like are given, interpreted and responded to. Unfortunately, these are considered trivial and therefore unnecessary to warrant any academic study". 
From this assertion, it appears that the study of any particular language should take into consideration not only its internal structural aspect but also some sociocultural parameters. Then, researchers should also be in connection with notions such as greetings, compliments and invitations.

\section{Methodology}

Inductive, pragmatic and comparative approaches have been used as interdependent approaches for writing this paper. I have used inductive approach based on participation- observation in Likuba language. Then, I discussed with Likuba native speakers who gave me free answers as possible. In addition, pragmatics has been chosen because Likuba greetings are sometimes made of proverbs and their explanations depend on context. As regard English, a great number of scientific documents on this language and my own training appear substantial for the writing of this paper. Finally, from comparative approach, I have checked if Likuba, one of Congolese languages bears the same features as English, an Indo European language to bring out their similarities and dissimilarities.

This paper is organised into three sections: Greetings functions, types of greetings and analysis, and greetings structural organization. These interdependent sections are subject to the aim to be achieved. To start with, greeting definition should be given. In this respect, Akindele(op cit:3) states:

"Greetings can be described as the exchange of expressions, pleasantries or good wishes between two people or a group interacting for the purpose of fulfilling social obligations or establishing interpersonal relationship. Insome cases, greeting is used as a prelude to the making of a proper conversation or introducing the topic talk"

From this assertion, it is retainable that greetings constitute an exchange of good wishes between individuals for establishing a good social atmosphere with the other members of the community and a means of topic introduction.

\section{GREETINGS FUNCTIONS}

The present section is concerned with general functions of greetings through the world and since they are made of several functions, to be precise, each function is considered as a sub-section. They can be presented as follows: contact establishment, religion and geographical areas distinction, appreciation of relationship degree between participants, an expression of participants characteristic, and Likuba view of greetings and English one. Interestingly, this last point purports to bring out some specificities on both languages under discussion.

\subsection{Contact Establishment}

In our day-to-day interaction, greetings are seen as a means which help to achieve this goal. This is observable at work place, church, market...etc. Customs of greetings use vary from one linguistic community to another. It may be made of body motion or not. Currently, because of Corona Virus, most of countries share almost the same type of greeting gestures.

\subsection{Religion Distinction}

The distinction of individual's religion can be made through greetings. That is why, "Salamalekoum" is the Muslim greeting mark, "Shaloom" for the Hebrew. Actually, this one is used by most of Congolese newly born churches. In Congoo, catholic church is made of different prayer groups and each of them has a particular way to greet its own members. For instance, the members of "Yamboté" at Saint Jean Baptiste in 1990s usedthe name of their group to greet themselves as follows: "yamboté" and the answer was "toujourspartout".

\subsection{Geographical Area Distinction}

Greetings deal with individuals geographical distinction. Accordingly, in Lingala "Mboté" and "Mboténayo" meaning good morning/ afternoon/ evening/night help distinguish a Congolese from Brazzaville from this of DRC. So, the former uses "Mboté" and the latter "Mboténayo". Interestingly, the word "yo" refers to "for you". In addition, "Mibaramo" is Centrafrican inhabitants greeting mark. Then, "Bonjour" is used by francophone. The Rwandese greeting is "Amakourou"; Buenos dias and Nihao are respectively used by Portugese and Chinese. Finally, the Malians say "Anisoukouma", the Senegalese greet themselves as follows: Diamangafanone (Wolof) and Diawanlo (Peul). 


\subsection{Appreciation of Participants Degree of Relationship}

The expression of greetings symbolizes good or bad relationship between different members of communities. As a matter of fact, people whose relationships are in harmony express it through greetings. However, the lack of greetings in a relationship can express some conflicting aspects between friends. In the way, the lack of greeting between a teachers and learners at the beginning of the course may explain a bad course impression for the learners.

\subsection{Participant Characteristics}

Since greetings are part of every conversation, it is important to know how to use them properly and with confidence. Then, the first moments of an interaction with someone are crucial because they set the tone for the conversation to follow. If someone starts a conversation doubting and unsure of what he/she is saying, his/her performance for the rest of the conversation will be weak. So, it is important to feel confident when greeting someone because he will quickly form a first impression of you that may be hard to change later on. If you greet someone with confidence, he or she will feel more comfortable with you and will form a positive impression. However, if you stumble around and are not sure of what you are doing, they may misjudge your true level of the language you use and speak to you differently than you would like.

\subsection{Likuba Greetings}

Each community has its own particular cultural values. That is why, Likuba case cannot be an exception. Then the present sub-section is concerned with the consideration of greetings in the following aspects: social integration and politeness.

According to the Likuba, the use of greetings aims at contributing to the social integration. Actually, people who get used greeting others are said to be kind and capable of living with the others. So, this attitude may give them some responsibilities in the community.

The Likuba consider greetings as an opportunity to express their good level of education. As a matter of fact, while greetings, at any time and place, the female or male youngers are the ones who initiate greetings towards adults. Sometimes, an adult may start greeting but this practise is seldom. Finally, in this linguistic community, the use of greetings several times by the same participants the same day is not boring.

\subsection{English Greetings}

Since, each notion bears its specificities, it is worth bringing light on the consideration of greetings by English people emphasizing on social integration aspect.

For the English, having a good command of politeness namely greetings facilitates foreigners social integration in England. Sometimes, on December, it is advised to foreigners to know Christmas song. Kissing practice while greeting is the main concern of very closed persons. Colleagues greetings are made holding each other hands, the near colleagues hold of each other arms and the very closed use kissing. Then "How are you doing" is considered as politeness rule of greeting and does not always require an answer. The formal or informal aspect of greetings depends on speakers types of relationships.

It can be noted that greetings govern most field of activities of English and Likuba. But the consideration of greetings as a mark of deference is the main concern of Likuba.

\section{TYPES OF GREETINGS AND ANALYSIS}

In general, life items are made of different categories and sub-categories. That is the reason why, I divide the present section into four sub-sections as follows: greetings period, festivals, condolences and proverbial ones. Note this one is a Likuba specificity because there is no equivalence in English. Presentation of greetings and their analysis will take place simultaneously in both languages.

\subsection{Periodic Greetings}

Greetings are divided into different periods along a day and the present sub-section can be presented in the following way: English greeting periods and Likuba ones. 


\subsubsection{Periodic Likuba Greetings}

In Likuba, greetings are divided into three parts: morning, afternoon, and evening or night. Cli and San are considered as participants of the present morning greetings.

Example:

San: Ô séga?

Cli:Eh, nanô?

San:ÔKèwani?

Cli:Nakèlibongo

San:Okèlibongookèndé?
Literal translation

Have you wakenup ? Good morning

Yes, and you?

Where are you going?

I am going to the port

What are you going to do there?

Cli:Nakèlibongoeponga a sani I am going to wash plates

It comes out that the word "osega" derives from the verb "esega" which means to wake up. This type of greeting is totally dependent on the morning. A part from this greeting, it is possible to greet someone at any time using the following words: mboré, binongo which can be respectively translated as follows: be greeted, are you there. Their difference is that these greetings occur at any time. Interestingly, the term "Ayindate" or "it is getting night" is a type of Likuba greeting in connection with evening or night and the answer is "Dzambite" or "no problem" if the day was good for the person being greeted. In the contrary, he may inform his speaker what went wrong with him or her.

\subsubsection{English Periodic Greetings}

English periodic greetings consists of four parts: morning, afternoon, evening and night. The morning greeting is considered as an example among others. Then, at any moment of the day, the content of the conversation depends on the degree of relationship between participants.

\subsection{2. a. Morning Greetings}

Speaker A: Good morning

Speaker B: Good morning

Speaker A: How are you?

Speaker B:I am fine, and you?

Speaker A: I am fine too.

Speaker B: Good bye!

Speaker A: Good bye!

This type of greeting of is concerned with two participants who know each other; if not the conversation should not last. Then, the fact of greeting someone without continuing conversation is sufficient in day-to-day interactions.

\subsubsection{Festival Greetings}

Day -to-day life offers opportunities linked to celebration of some joyful events such as the celebration of wedding and birthday ceremonies. They consist of special greetings. Here, a dialogue as such is not required because participants are supposed to be concentrated on music, eating, drinking .... and so on. Therefore, both languages festival greetings are going to be presented in this sub-section.

In Likuba linguistic community as in other African geographical areas, festivals consist of wedding ceremonies, celebration of new year, birth of twins, reception of new members in traditional institutions, the enthronement of new traditional chiefs, new born naming ....and so on. Accordingly, in the Likuba community, during a wedding ceremony for instance, the word "Longogna" is used to greet the couple and the answer is "Melesi" meaning "Merci" or "Thank you". The same answer is also similar to someone who is well-dressed. In fact, the Likuba pronounce the word "putulu" in this circumstance. Then, the term "ibagha" meaning "a brave man" is a greeting term made of congratulation of someone who has played an important role in a given situation such as hunting part, fishing, ...etc. Finally, "Boyetela" meaning together we have arrived is a greeting term expressing 
the celebration of the new year. As regard English, words such as Happy birthday, Merry Christmas and Happy new year... and so on reflect this people expression of joyful events. At the same time, they are considered as greetings mark.

\subsection{Commiseration/Condolences Greetings}

Dead events constitute an opportunity during which people use special types of greetings for people who lost their dear friends, relatives or parents require comfort during the mourning period. This type of greetings is not made of a long conversation as well in English as Likuba.

Generally, an afflicted person whose moral is already upset, does not speak much and a long conversation with him or her seems boring. That is why, sentences such as "Take comfort my friends" or "Don't be downcast" are used and the answer is "Thank you. However, according to Likuba people, the type of greeting made of condolences is often a sentence describing a sad situation whose the greeted person is victim. Then, the answer made of low voice is short and can be illustrated as follows:

Speaker A: Yagokulipasimaisnganano o kuminatengandooeliekandza (You were in suffering but I did not come because I was ill).

Speaker B: Pasiniango (difficult mother).

\subsection{Likuba Proverbial Greetings}

Likuba greeting particularities consist of "Losako" or "Be greeted older". It is a greeting specificity expressing a special mark of deference towards adults and other members of family who are supposed to play the first role. For instance, a bride-to-be who did not give "losako" to one of the members of his in-law namely father or brother was submitted to some complications later during the wedding ceremony and this one was obliged to pay an amount of money to repair that fault if not the marriage could not take place.

Besides, "Losako" was mostly used by male persons than female ones whereas, nowadays, because of modernism, their use no more depends on gender. The following lines are made of illustrations which consist of a conversation of two participants. I have named them A(first) and B(second). Finally, a sample of 11 proverbs will be analysed according to their different functions divided as follows: work promotion, avoid bad company, prudence, ingratitude condemnation, perseverance, avoid precipitation, honesty, challenge spirit, solitude condemnation, mockery condemnation, politeness, mastering of social classes, avoid jealousy and judgement.

Speaker A: Losako

\section{Speaker B1: Niangumosolomosala}

The literal meaning of this proverb is the mother of money is the job. Such a proverb raises the place work and condemns laziness. It is a kind of awaking in the framework of working for the Likuba people. In fact, it teaches young people not to depend on their parents at a certain age and prevents them from bad practices for most of the cases, lazy young men prefer to win their life without making some efforts; this attitude exposes some of them at sorcery.

B2: Mokindza ma ngaintsolo

This proverb is literally translated as follows: "My fart smells badly". It is a piece of advice against bad companies.In fact, everybody releases gas from the bowels. However, from this proverb, it appears that in a group, only one member is accused to be at the origin of disgusting gases. This situation shows that we must avoid bad companies. Accordingly, in the framework of good relationships, people should tell truth to each other instead of being adept of gossiping. Therefore, the present proverb teaches people to avoid bad entourage. It is synonymous with following one:

\section{B3: Dzoandzungu}

Literally, this proverb compares cooking pot to a stupid person. Actually, since the cooking is always exposed on fire while cooking and considering the fact that it plays a substantial role, however it does not enjoy any profit, this metaphorical proverb is against ingratitude. Indeed, being grateful is the expression of good education for this practice raises individuals. Then, it learns people gratitude notions. 


\section{B4:Etsetsegemonanoolangaté.}

The literal translation of this proverb is the following:"etsetsege", a kind of fish cannot feel tired while swimming. Indeed, it teaches people on perseverance virtue for it is the key success in every domain of life and encourages people not to consider their failure as the end of their life and is in connection with "Mpikolotomba" or "perseverance brings success".

\section{B5: Ekoraambangoekibanayémé}

It is literally translated as follows: when you are running, you will suffer. As a matter of fact, the answer recommends people not to be hurry in life in order to avoid mistakes and asks people to be slowly and sure for precipitation often exposes to all sorts of obstacles. It is synonymous with "Epalanamuakooyina" or "a canoe cannot capsize when you have a recipient to put out water.

\section{B6: Boborobolamudiambookulaté.}

This answer is translated in the literal way in the following way: kindness is good but one must not be condemned. In fact, this proverb makes the promotion of honesty. In fact, in Likuba, an honest person is respected and capable to have some responsibilities in connection with village managements. However, the day he will commit a bad practise such as rape, robbery, sorcery ... and so on, he will no longer be trusted by the other members of the community and can be replaced by a new one.

\section{B7: Kumbaayumbindzoto}

The literal translation of this proverb is "The tortoise has bent its feet to wait for. The word tortoise is used as a metaphor condemning the passivity attitude in life. The present proverb raises the challenger spirit for a dynamic spirit cannot reduce someone to vulnerability and also it teaches to be prompt in front of opportunities.

\section{B8: Bopendza kuku té.}

The present greeting is "solitude no palaver. It encourages solidarity in human being relationships. Accordingly, solidarity characterizes the Likuba everyday life and a member of community who is not solidary towards the others has difficult social integration. Therefore, this attitude prevents one individual from enjoying community advantages. For instance, in the case of mourning or wedding ceremony, he or cannot have assistance of the other members of the community.

B9:Botondolo a sekimbia

This proverb literal translation is: "Tondolo", a kind of fruit has laugh at the palm nut. In fact, both fruits are considered as two very poor people who criticize each other in spite of their own social conditions. This proverb condemns mockery of individuals social status for life is considered as a circle; the one who is seen as a non-value object may become rich and vice versa. It is similar to the proverb "Mokilimayiyabuato" or "Life moves like water" or "Ezuimoningakoséketé" or " Don't laugh at someone who is crying because we don't know the future".

\section{B10: Moyokokeleté}

It is literally translated " a poor man is never in anger". This proverb means that people who can't afford should not complicate things; they should enjoy their benefactors' advantages. Instead of complaining about the quantity of the gift that they have received.If not he will not receive anything. This proverb purports to teach people about the mastering of social classes.

\section{B11:Momboro lo lisangumoromepoundzan'epoundza}

The present greeting is literally translated in the following way: each seed maize grows one by one". In the day -to-day interaction, it advises people to avoid jealousy apart from marriage matters.Actually, this bad feeling exposes people to sorcery.

\section{B12:Dzamanamorooyebaeyu}

The literal translation of this greeting is "live with someone to know his/her behaviour". In fact, it means that it is not possible to judge someone from a distance. That is why, in Likuba community, before marriage, the parents asked their bride-to-be to share first the same home so that the partners know each other behaviour and later, they will decide to be married or not. The moral lesson from this proverb is: don' $t$ trust appearances. 
It is noticeable that this section is made of one specificity which does not exist in English namely proverbial greetings. This type of greeting is the whole life of Likuba community.

\section{Structural ORganization Of English AND LikUba GREetingS}

In analysing the structure of English and Likuba greetings, I focus on the theoretical framework of discourse analysis as proposed by linguists such as Sinclair and Could Thard (1975), Ventola (1987), and Akindélé $(1988,1990)$. According to them, greetings are made of the following parts: opening or prefatory, informatory, pre-closing and closing. In fact, the first word refers to greeting terms which initiate a conversation, the second deals with questions and answer, the third consists of greeting words that people use before closing their conversation, its use appears facultative. Finally, closing is pronounced to end a given conversation. Note that this analysis is based on the form and not the content for in previous pages, this aspect has been already treated in both languages. This section is composed of the aspects which follow: formal greetings and informal ones which are supposed to contain each type of greetings.

\subsection{Formal Greetings}

This type of greetings is used when interacting with other people who are supposed to be older to us and superior in term of social status in connection with politico-administrative tasks such as boss, supervisor, manager... and so on. Sometimes, it is also used when offspring or children address to their relatives or parents and acquaintances.

\subsubsection{English Formal Greetings}

In English, formal greeting is mostly used in an academic place or in formal situations such as professional meetings. It is also used to establish professional or friendship links with natives. It will be presented through a conversation between two participants and its content is made of standard Language.

Example

Gem: Good morning/afternoon/evening/night/hello! (Opening or prefatory)

San: Good morning/afternoon/evening/night/hello! (opening or prefatory)

Gem: How are you?(informatory)

San: Fine tha1nks and you?(informatory)

Gem: I am fine

informatory

San: Good bye! (closing)

Gem: Good bye!(closing)

It appears that English formal greeting is concerned with three parts divided as follows: opening, informatory and closing. In fact, opening or prefatory is used by both participants as the introductory words; their use is always identic by both of them. Then, informatory which consists of different questions and answers depends on a type of relationship of participants. In fact, people who know each other may converse during some minutes whereas the unknown participants most of the time only use opening greeting.

\subsubsection{Likuba Formal Greetings}

In Likuba, formal greetings are considered as the main ones. They can be used as well by youngers as older at the same time. However, the context of their use varies from one age category to another. This type of greetings is made of "Losako" meaning "be greeted".

Example

Speaker A: Losako(opening)

Speaker B: Leloyayo, lobiyanga

(Informatory closing)for me

$$
\text { Literal translation Meaning }
$$

Be greeted Be greeted

today for you, tomorrow life matters changes 
Speaker A: Kuabilogho

(opening)

Speaker B: Bonangabato

(Informatory closing)

It comes out that this greeting consists of two parts: opening and informatory closing. Note that this one deals with the answer and the end of the conversation. Then, the repetition of opening greeting appears facultative and aims at having the greeted person a viewpoint on a given topic; it is a kind of insistence. From this structure, it is understandable that speaker A is younger than speaker B because a part from exceptions, in this community, a younger should initiate greetings.

\subsection{Informal Greetings}

Informal greetings is made of our relationship with friends, family, classmates, and acquaintances. This type of greeting is sometimes concerned with a boss and an employee or a traditional chief and the other members of the community in an informal situation. Likuba is made of a great deal of informal ways of greetings, but I am going to use the following one, considered as a sample.

\subsubsection{Likuba Informal Greetings}

Since languages are made of registers, greetings cannot be an exception. This type of greeting is used by participants sharing a non-standard vocabulary. Note that sometimes, they may move from informal to formal depending on circumstances.

According to the Likuba, informal greetings can be used in relationship between friends. Sometimes, when relationship between relatives, parents and children or offspring are friendly, they use to greet each other informally. To be clear, a word is going to be said on their literal translation and meaning. Lkuba has several words of an opening informal greetings. However, in my example, I am going to consider one type among others. This choice depends on the data I have at my disposal.
Example
Literal translation
meaning

Speaker A: O ngôberege? Over there how? Be greeted and How are you?

(opening)

Speaker B: Dzambitè

problem no

I am fine

(informatory)

Speaker A:O kèwaniWhere are you going?

(informatory)

Speaker B: Na kèndzando I am going to the market

(informatory)

Speaker A: Loyasébengo See you like this

Next time

(closing)

Speaker B: Eh

yes

Next time

(closing)

From this conversation, it is retainable that there are more informatory greeting words than opening. This implies that both participants know. In fact, A is seen considered as older than B. This can be justified by the fact that in Likuba geographical area, adults can initiate questions during conversation though sometimes, this task may be fulfilled by youngers.

\subsubsection{English Informal Greetings}

This type of greetings is used between friends, colleagues, a chief and his collaborator in an informal situation such as party, mourning, fishing or hunting part... and so on. 
Example

Speaker A: Hi Peter

opening/ prefatory

Speaker B: Hi Jack

opening/prefatory

Speaker A: How are you doing?informatory

Speaker B: I am so, and you?informatory

Speaker A: I am goodinformatory

Speaker B: Bye for now Closing

Speaker B:See you ! Closing

It comes out that this English greeting is made of three parts: opening, informatory and closing. Accordingly, opening and closing are always used in pair. From this conversation, it is retainable that informatory appears like the

Center part of the dialogue. It's length depends on of the type of relationships between two participants.

From this third section, it is retainable that both languades have formal and informal greetings whereas their consideration are closely dependent on their cultural values.

\section{CONClusion}

It comes out that English and Likuba greetings consisted the backbone of the present work. As a matter of fact, this work has brought light on consideration of greetings by both people under discussion with a focus on their socio cultural values. Then, in spite of some common points between their greetings system, the present analysis has demonstrated that Likuba greeting is not used as a simple act of pleasure and a means expressing contact between individuals. It is rather an expression of the whole life of this people.

\section{REFERENCES}

AKINDELE D F, 1990 , "A Sociolinguistic analysis of Yoruba greetings" Journal of African Languages and Cultures, 98-113.

AKINDELE D F, 2017, "Lumela/Lumela: A Socio-Pragmatic Analysis of Sesotho Greetings" Nordic Journal of African Studies:1-17

BAMISAIYE D F, 2001, A comparative Sociolinguistic Study of Greetings in English and Yoruba, M.A (English) Research Project, University of Ibadan, Nigeria.

IYIOLA Amos Damilare, 2015, «Etude comparée Des Salutations Françaises etYorubas », Journal of Literature, Languages and Linguistics, Vol.11, pp.7-17.

Ken, Bach \& Robert M.Harnich, 1979,Linguistic communication and speech acts, Cambridge:M.T.Press.

Roman Jackobson, 1960, Linguistics and Poetics, style in Language, Cambridge, Mass, Mit Press.

Searle and Vanderveken, 1985,Foundations of illocutionary logic, Cambridge.

\section{WEBOGRAPHY}

https://fr.babbel.com/fr/magazine/le-guide-ultim-pour-savoir-saluer-partout-dans-le-monde.

https://www.research.net/publication/327743980-Etude-Com...

WWW.Presses-id.fr/IMG/Salutations.

Citation: Gemma Cliff Nguia Oniangué "Contrastive Analysis of English and Likuba Greetings" International Journal on Studies in English Language and Literature (IJSELL), vol 8, no. 12, 2020, pp. 44-52. doi: https://doi.org/10.20431/2347-3134.0812003.

Copyright: () 2020 Authors. This is an open-access article distributed under the terms of the Creative Commons Attribution License, which permits unrestricted use, distribution, and reproduction in any medium, provided the original author and source are credited. 